引用格式: 刘庆生, 刘高焕, 黄肿, 等. 蒙古高原乌兰巴托-丰镇草地样带植被与土壤属性的空间分布 [J]. 资源科学, 2016,38(5): 982-993. [Liu Q S, Liu G H, Huang C, et al. Spatial distribution of vegetation and soil properties on the Ulan Bator-Fengzhen transect on the Mongolian Plateau[J]. Resources Science, 2016,38 (5) : 982-993]. DOI: 10.18402/resci.2016.05.17

\title{
蒙古高原乌兰巴托-丰镇草地样带植被与 土壤属性的空间分布
}

\begin{abstract}
刘庆生 ${ }^{1,2}$, 刘高焕 ${ }^{1}$, 黄 肿 $^{1}$, 姚治君 ${ }^{3}$, 黄河清 ${ }^{3}$
(1. 中国科学院地理科学与资源研究所资源与环境信息系统国家重点实验室, 北京 100101 ;
\end{abstract}

2. 江苏省地理信息资源开发与利用协同创新中心, 南京 210023 ;

3. 中国科学院地理科学与资源研究所, 北京 100101)

\begin{abstract}
摘 要: 荒漠化是全球性的一个环境问题。植被与土壤是土地荒漠化研究的主体,综合分析植被与土壤特征 及其空间分布, 对于研究干旱区、半干旱区荒漠化发生、发展过程具有重要的理论和现实意义。基于 2013 年 8 月蒙 古高原乌兰巴托-丰镇草地样带植被与土壤调查数据, 对其空间分布特征进行了分析, 结果表明: 蒙古高原乌兰巴 托一丰镇草地样带上, 植被覆盖度、植物种类数量、土壤有机质、土壤速效钾、土壤砂粒百分比具有相似的空间分布 规律, 呈现南北高, 中间低的空间分布形态; 土壤相对干旱、土壤盐渍化程度轻, 蒙古国境内土壤以中性为主, 中国 内蒙古境内土壤以碱性为主; 蒙古国境内的草地样方出现灌丛的现象比中国内蒙古境内多, 从一个侧面反映了蒙 古国草地退化相对严重; 蒙古国境内土壤全氮极贫乏、中国内蒙古境内土壤全氮相对丰富。从一个侧面反映了中 国内蒙古境内相对发达的农业开发和人类活动影响。研究成果可为区域植被恢复和荒漠化防治提供科学依据和 资料支撑。
\end{abstract}

关键词: 蒙古高原; 草地样带; 植被; 土壤特征; 空间分布

DOI: $10.18402 /$ resci.2016.05.17

\section{1 引言}

荒漠化是全球性的一个环境问题,已影响到世 界六大洲的 100 多个国家和地区。中国是受荒漠化 危害最为严重的国家之一,据国家林业局第四次中 国荒漠化监测结果显示, 国土面积的 $27.33 \%$ 为荒漠 化土地, 在全球气候变暖背景下, 仍有可能进一步 扩展 ${ }^{[1]}$ 。土地荒漠化是干旱、半干旱和亚湿润干旱 区由于气候变化和人类活动等各种因素造成的土 地退化。目前, 干旱区荒漠化的研究受到前所未有 的重视,已成为国际气候系统及全球变化、生物多 样性、土地退化与区域可持续发展等研究中最活跃 的领域之一 ${ }^{[2]}$ 。草地退化是土地荒漠化的主要表现
形式之一, 以草本植物为主要植被群落的草地被以 灌丛为优势群落所替代是草地退化或荒漠化的显

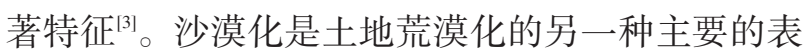
现形式, 表现为原生植被逐渐被沙生植物和沙地先 锋植物取代、土壤中细物质和有机质逐渐减少、土 壤养分重新分布的过程 ${ }^{[4,5]}$ 。植被作为土地重要的 构成要素, 对自然环境最为敏感, 是对某一地区生 态环境的综合反映。植被覆盖度指示着景观环境 因子的适宜程度,因而可作为表征土地荒漠化的一 个直接的主导性指标 ${ }^{[6,7]}$ 。土壤是植被生长最重要 的环境因子, 是荒漠化发生发展的物质基础, 土壤 水分和物理化学性质是了解土壤与植被关系以及

收稿日期: 2015-12-10; 修订日期: 2016-02-05

基金项目: 国际科技合作项目: “蒙古高原干旱半干旱气候灾害及防治研究”(2013DFA91700)。

作者简介: 刘庆生, 男, 山西忻州人, 博士, 副研究员, 研究方向为生态环境遥感。E-mail : liuqs@1reis.ac.cn

通讯作者:刘高焕,E-mail:liugh@lreis.ac.cn 
荒漠化发生的基础 ${ }^{[8,9]}$ 。由此可见,植被与土壤是土 地荒漠化研究的主体,综合分析植被与土壤特征及 其空间分布,对于研究干旱区、半干旱区荒漠化发 生、发展过程具有重要的理论和现实意义。

由于地域广大、国界分割等诸多原因,蒙古高 原资源环境研究并不十分深人 ${ }^{[10]}$, 区域尺度上多集 中于利用遥感、GIS 以及模型模拟等手段,开展区域 植被覆盖变化 ${ }^{[11]} 、$ NDVI 时空格局 ${ }^{[12,13]}$ 以及土地利用 与土地覆被变化 ${ }^{[14-16]}$ 等研究, 这些研究因缺少地面 第一手资料支撑, 大多是区域宏观描述, 尚缺乏基 于全面的科学考察、采样资料积累进行蒙古高原大 尺度区域植被、土壤属性空间分布格局和分异规律 的研究。巴图娜存等给出了蒙古高原乌兰巴托一锡 林浩特草地样带上植物物种类型和数量的空间分 布格局及其变化规律 ${ }^{[10]}$,但未对土壤属性的空间变 化规律进行研究。

为此,本文利用 2013 年蒙古高原乌兰巴托-丰 镇草地样带的样方调查和土壤测试分析成果, 开展 植被与土壤属性的空间分布格局及其变异特征研 究, 以期为区域植被恢复和荒漠化防治提供科学依 据和资料支撑。

\section{2 研究区概况}

蒙古高原地处亚洲大陆腹地, 主要分布在中国 的内蒙古自治区和蒙古国全境,是一个相对封闭的 内陆生态地理单元 ${ }^{[14]}$ 。蒙古高原是欧亚大陆温性草 原的核心区，包括草甸草原、典型草原、荒漠草原和
戈壁等类型, 且以典型草原分布最广 ${ }^{[10]}$ 。蒙古高原 除东部、南部少数地区,年降雨量一般少于 $400 \mathrm{~mm}$, 为典型的干旱、半干旱大陆性气候区, 土壤风蚀明 显, 土地荒漠化严重, 是影响中国的主要沙尘源区 之一 ${ }^{[17]}$ 。蒙古高原面积广阔, 是一个巨大的平缓起 伏的高原地区, 其平均海拔 $1580 \mathrm{~m}$,地势自西向东逐 渐降低 ${ }^{[10,18]}$ (图 1)。在蒙古高原不同气候地带内的 不同生境中植被与土壤的发育产生了多样的生态 系统类型。在山地半湿润气候带形成了森林、草甸 和草原的植被组合和灰包森林土与漂灰土,在广大 的半干旱气候带,发育形成了草原植被和黑钙土与 栗钙土,植被类型有大针茅、克氏针茅、沙筒、柳灌 丛等,在干旱地带发育着荒漠草原植被和棕钙土， 在极干旱气候带是荒漠植被与灰棕漠土的组合,植 被类型有霸王柴、泡泡刺、麻黄、沙拐束、松叶猪毛 菜等 ${ }^{[18]}$ 。

\section{3 数据来源与处理}

\section{1 样带设计和采样}

蒙古高原乌兰巴托-丰镇草地样带起于蒙古国 乌兰巴托市,止于内蒙古丰镇市。在蒙古国境内, 考察时间为 2013 年 8 月 7 日到 2013 年 8 月 13 日, 考 察路线从乌兰巴托出发向西到达中央省呼斯泰岭 自然保护区 (沿途土地覆被主要为草地, 草地植被 覆盖较高, 无荒漠化特征,并有少量耕地,耕作植物 以油菜和荍麦为主, 设置了 5 个草地样点), 向东到 达达克鲁伦河岸边 (沿途山坡为林地, 平原地带主

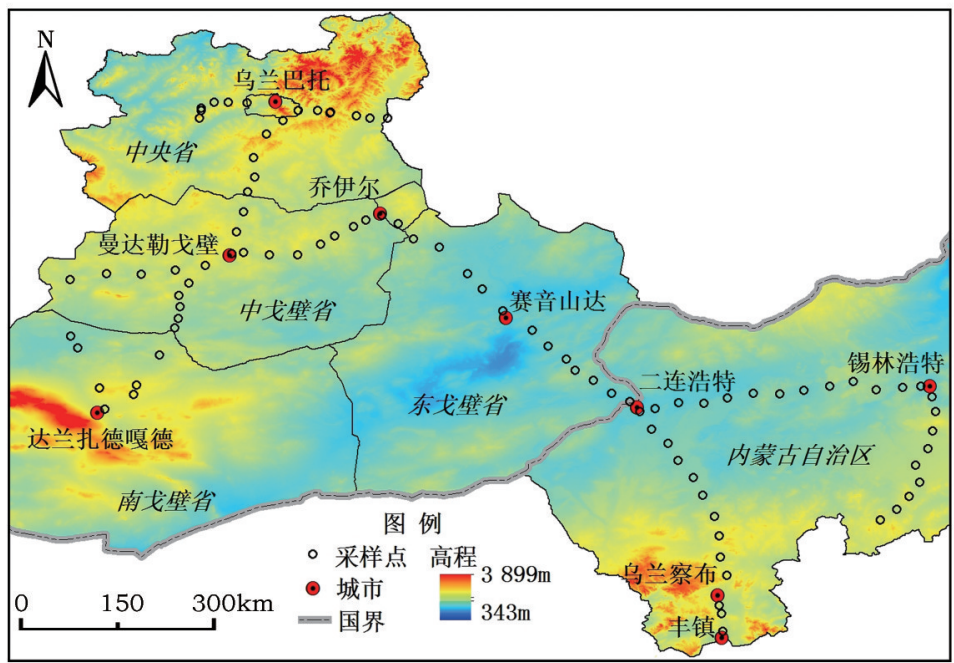

图 1 研究区地形及蒙古高原乌兰巴托-丰镇草地样带和采样点位置

Figure 1 The topography of the study area and the geographic location of the Ulan Bator-Fengzhen transect and sampling points 
要为草地, 其中部分出现沙化特征, 设置了 6 个草地 样点),之后,向西南方向经中戈壁省省会曼德勒戈 壁一直到南戈壁省会达兰扎德嘎德 (沿途为草地、 戈壁和沙漠区,植被稀少, 主要为沙葱、锦鸡儿等沙 生植物, 偶有斑丛状小沙丘, 设置了 18 个草地样 点), 接着向西北方向经曼德勒戈壁抵达戈壁苏木 贝尔省省会乔伊尔 $($ 植被覆盖度自东向西有下降趋 势, 从荒漠化草原向荒漠转变, 设置了 14 个草地样 点), 最后, 向东南方向出发经东戈壁省会赛音山达 市到达边境城市扎门乌德 (沿途主要为荒漠化土 地, 植物种类较少, 植被覆盖度总体较低, 且变化不 大, 见有明显的侵蚀地貌，设置了14个草地样点）。 在中国内蒙古境内, 考察时间为 2013 年 8 月 19 日到 2013 年 8 月 23 日, 考察路线从丰镇市开始向北经乌 兰察布市到二连浩特市 (从南到北由耕地为主, 逐 渐向草原、荒漠过渡, 植被覆盖度逐渐降低, 人类活 动以放牧为主, 设置了 13 个草地样点), 之后向东到 达锡林浩特市 (自西向东出现荒漠向草原过渡的特 征, 植被覆盖度逐渐上升, 设置了 12 个草地样点), 最后, 向南出发抵达太仆寺旗 (沿途土地覆被为草 地, 大部分地区设为围栏禁牧区, 植被覆盖度较高, 设置了 9 个样点), 采样点位置示意图见图 1。

植物样方调查和土壤采集基本流程是: 首先选 择具有代表性的位置放置 $1 \mathrm{~m} \times 1 \mathrm{~m}$ 样方框, 使用数 码相机垂直向下拍摄草地样方照片, 有经验的专家 估算植被覆盖度, 然后利用微距模式拍摄每种植 物, 利用 GPS 测定经纬度和高程, 利用 WET 土壤速 测仪测得样方内表层 $10 \mathrm{~cm}$ 土深的土壤温度、电导 率和湿度, 利用铁锹在样方内挖取 $0 \sim 10 \mathrm{~cm}$ 约 $100 \mathrm{~g}$ 土壤剖面样品, 并用速封袋保存, 记录草地类型、草 群高度和盖度、物种名称、人类活动等信息。

\section{2 数据处理}

因蒙古国的土壤样品无法带回国内,所以在蒙 古国采集的土壤样品由蒙古游牧畜牧业研究中心 处理分析, 内蒙古采集的土壤样品由中国科学院地 理科学与资源研究所理化分析中心处理分析。为 了对比分析, 事先约定了土壤样品测试分析方法, 均按中国土壤学会农业化学专业委员会编的《土壤 农业化学常规分析方法》皇星中规定的方法进行测试, 共测试分析了土壤全盐量、 $\mathrm{pH}$ 值、有机质、全氮、速
效磷、速效钾、砂粒百分比、粉粒百分比、黏粒百分 比等九个指标。

结合之前野外实测的土壤温度、湿度, 以及植 物种类、植被覆盖度、有无灌木等,共形成 14 个指 标, 用于植被与土壤属性空间分布特征研究。通过 分析每个指标的均值、方差、最大和最小值, 并参考 植被覆盖和土地利用类型情况, 进行奇异值检查, 然后使用统计分析加图示的方式直观反映植被与 土壤属性的空间差异。

\section{4 结果与分析}

\section{1 植被的空间分布特征}

选取反映草地退化的有无灌丛、反映生物多样 性的植被种类数量以及反映植被的景观环境因子 适宜程度的植被覆盖度等三个指标进行分析。

\subsection{1 有无灌丛指标分析}

草地原生植被被以灌丛为优势群落所替代是 草地退化或荒漠化的显著特征,因此按植被样方内 有无灌丛作为反映草地退化的一个指标。从有无 灌丛指标的具体统计来看, 91 个草地样方中共有 35 个样方中发现灌丛,约占 $38.0 \%$, 主要分布在乌兰巴 托-达兰扎德嘎德、乔伊尔-扎门乌德沿线,蒙古国 境内的草地样方出现灌丛的现象比内蒙古要多, 从 一个侧面反映蒙古国草地退化相对更严重, 见图 2 。

\subsection{2 植物种类数量特征分析}

植物种类数量是生物多样性指标之一。植物 物种数量的空间分布呈现南北高、中间低的特点 (图 3)。91 个草地样方内最少的植物种类数量为 3 种, 最多的为 8 种, 以乌兰巴托附近草地样方内植 物种类最丰富。

\subsection{3 植被覆盖度的空间分布}

植被覆盖度指示着景观环境因子的适宜程度， 是最常用的草地退化遥感分级指标。参照中国科 学院制定的全国土地资源分类系统中草地类型划 分的标准, 将植被覆盖度分为: $<5 \% 、 5 \%$ 20\%、 $20 \%$ 50\% 和 $>50 \%$ 等四级(图 4)。从植被覆盖度的 空间分布看, 与植物物种数量的空间分布规律类 似,亦呈现南北高,中间低的特点,在空间上形成乌 兰巴托-曼德勒戈壁-乔伊尔,锡林浩特-太仆寺旗， 以及乌兰察布-丰镇三个高值区, 植被覆盖度的低 值区恰好反映了赛音山达-二连浩特一线荒漠化严 


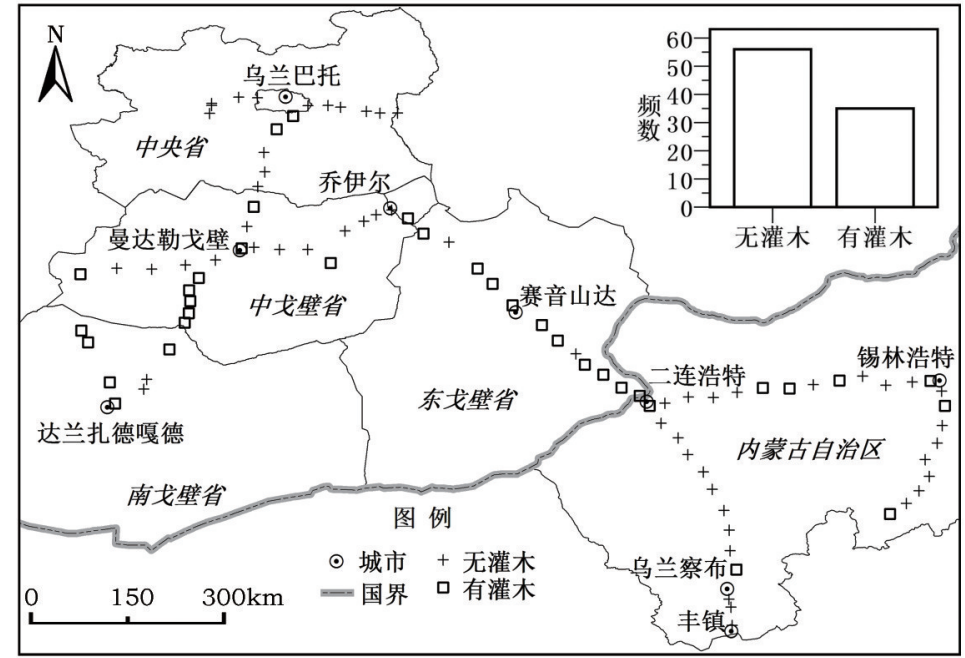

图 2 有无灌丛草地的空间分布

Figure 2 The spatial distribution of grassland with or without a brush

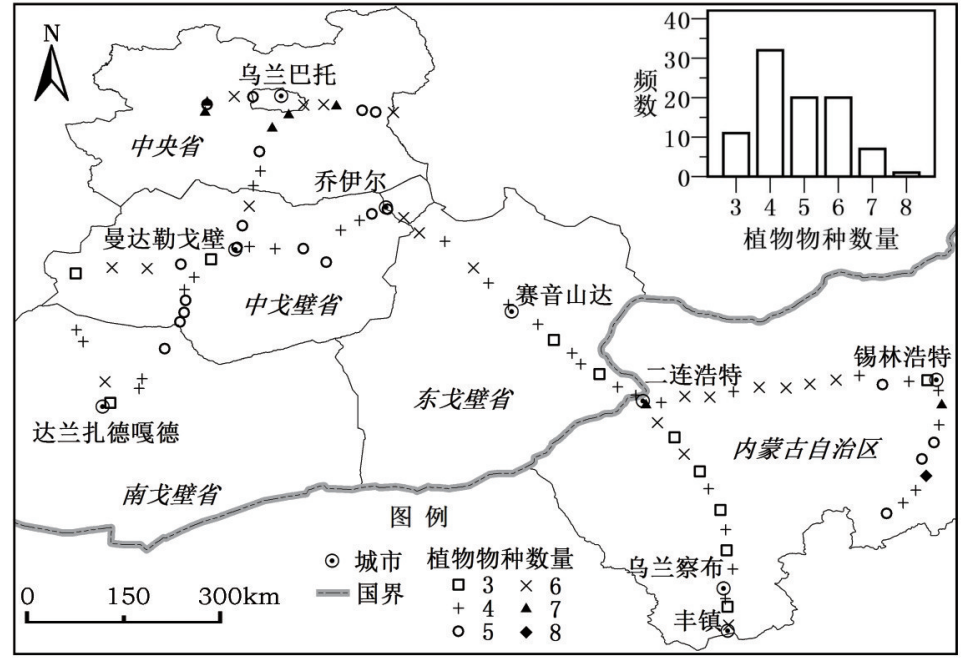

图 3 植物物种数量的空间分布

Figure 3 The spatial distribution of the number of plant species

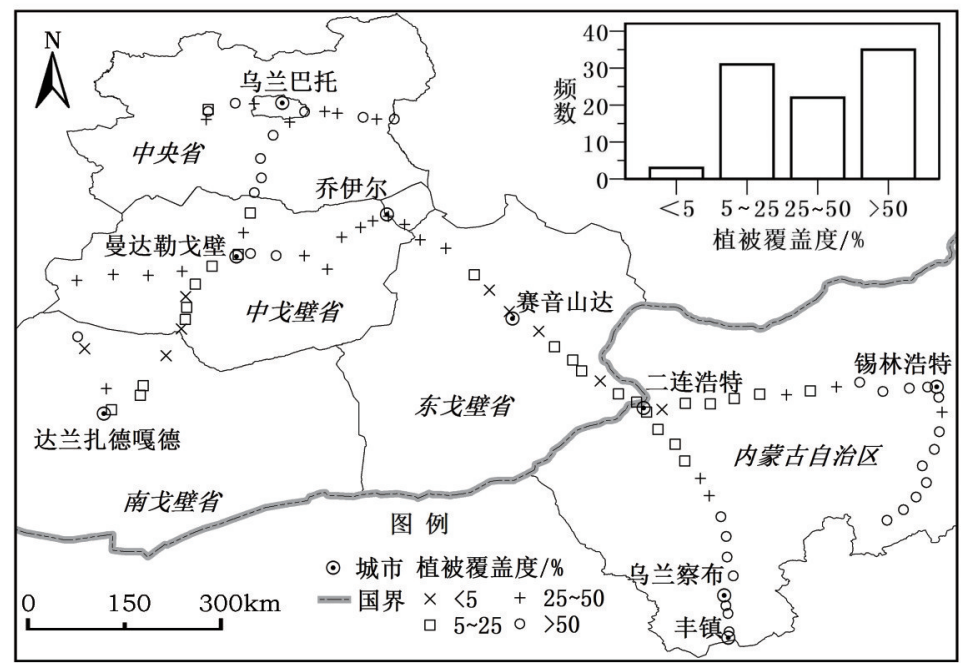

图 4 植被覆盖度的空间分布

Figure 4 The spatial distribution of vegetation coverage 
重的区域(图 4)。从植被覆盖度的具体统计指标来 看, 91 个草地样方中植被覆盖度最小值仅为 $2.0 \%$, 几乎全裸, 最大值为 $95.0 \%$, 植被生长茂盛, 差异明 显。植被覆盖度平均值为 $39.8 \%$, 标准差 $28.9 \%$, 变 异系数为 $72.6 \%$, 空间变异强。

\section{2 土壤属性的空间分布特征}

\subsection{1 土壤温湿度的空间分布特征}

在干旱和半干旱地区, 土壤水分是决定植被格 局和土壤状况的关键因素之一。尽管本次研究所 获土壤温湿度的时间不一,但也可从一个侧面反映 土壤状况。将土壤温度划分为三级: $<20^{\circ} \mathrm{C} 、 20 \sim 30^{\circ} \mathrm{C}$ 和 $>30^{\circ} \mathrm{C}$ 。参照土壤干旱程度和墒情分类标准, 以
及实际测定的土壤湿度范围,将土壤湿度划分为三 级: $<20 \%$ (重早)、20\% 40\% (中早)和 40\% 60\% (轻 早)。

从土壤温度的空间分布看,蒙古国境内土壤温 度普遍偏高, 这也许与考察时间上内蒙古晚了一周 多,在 8 月下旬测量所致(图 5)。从具体统计来看, 考察期间, 土壤温度最小值 $14.1^{\circ} \mathrm{C}$ 、最大值为 $40.2^{\circ} \mathrm{C}$ 、平均值为 $27.4^{\circ} \mathrm{C}$, 蒙古国境内与中国内蒙古 境内土壤平均温度分别为 $29.5^{\circ} \mathrm{C}$ 和 $23.9^{\circ} \mathrm{C}$ 。

从土壤湿度的空间分布看,乌兰巴托附近土壤 湿度较大, 但依土壤干旱程度和墑情分类标准来 看,仍属轻旱(图 6)。蒙古国境内的中央戈壁省和

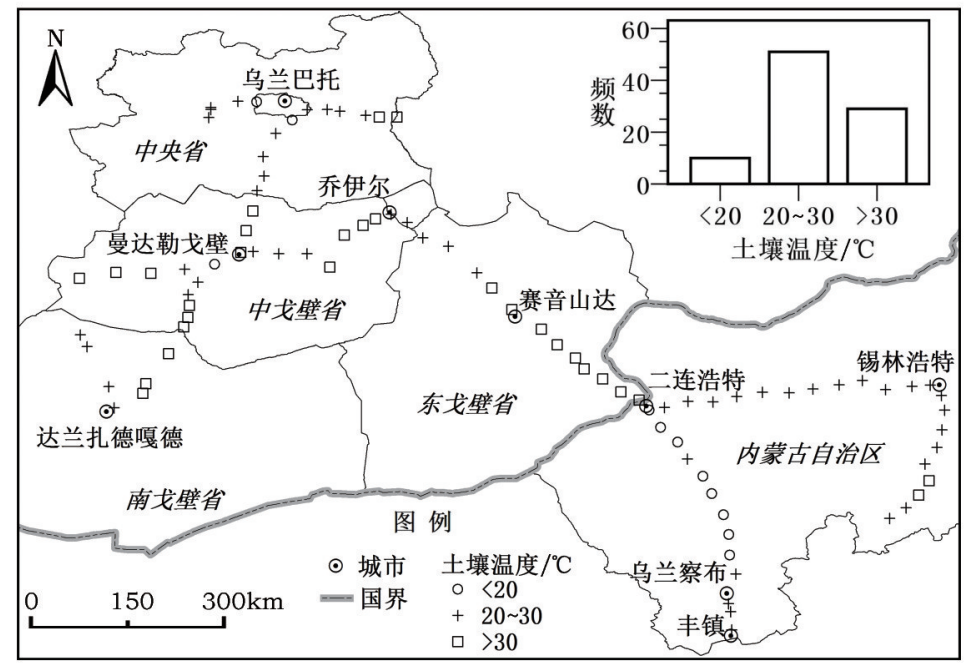

图 5 土壤温度的空间分布

Figure 5 The spatial distribution of soil temperature

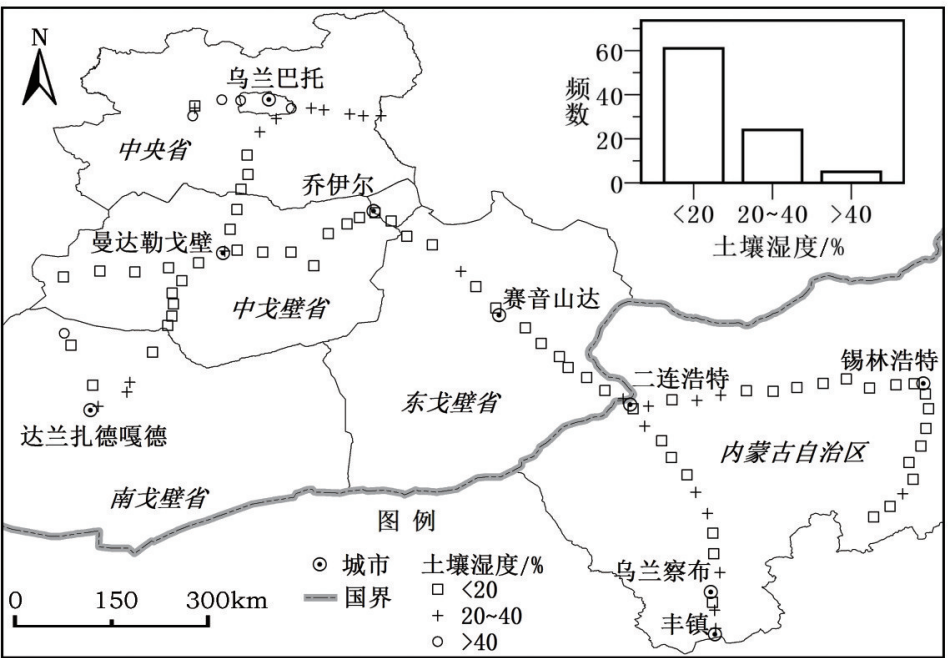

图 6 土壤湿度的空间分布

Figure 6 The spatial distribution of soil moisture 
东戈壁省, 中国内蒙古境内的锡林浩特-太仆寺旗 一带土壤干旱程度严重。从具体统计来看, 考察期 间, 土壤湿度最小值为 $6.0 \%$, 最大值为 $56.0 \%$, 平均 值为 $17.3 \%$ 。

\subsection{2 土壤全盐量与 $\mathrm{pH}$ 值的空间分布特征}

总体上看, 蒙古高原乌兰巴托-丰镇草地样带 土壤盐渍化程度较轻, 只有 5 个样点发生不同程度 的盐渍化,全部在蒙古国境内(图 7)。

土壤 $\mathrm{pH}$ 是影响土壤养分有效性的重要因素之 一。大多数养分在 $\mathrm{pH}$ 值 $6.5 \sim 7.0$ 时有效性最高或接 近最高。参照土壤 $\mathrm{pH}$ 分级标准以及样带 $\mathrm{pH}$ 的范 围, 将土壤 $\mathrm{pH}$ 值划分为三类: $<6.5$ (酸性) 、6.5 7.5
(中性) 和 $>7.5$ (碱性)。从具体的统计指标来看, 土 壤 $\mathrm{pH}$ 最小值为 6.3 , 最大值为 9.3 。酸性土壤仅占 $1.1 \%$, 中性土壤占 $33.0 \%$, 绝大部分为碱性土壤, 约 占所有样方的 $65.9 \%$ 。从空间分布上看, 仅有的 1 个酸性土壤样品位于纳来哈与巴嘎诺尔的中间地 带; 中性土壤绝大部分分布在蒙古国境内,主要分 布在乌兰巴托、曼达勒戈壁和乔伊尔附近。中国内 蒙古境内除锡林浩特市南部和太仆寺旗北部各有 一个样方为中性土壤外, 全部为碱性土壤(图 8)。

\subsection{3 土壤养分的空间分布特征}

土壤养分是土壤提供的植物生长所必需的营 养元素。土壤养分含量因土而异,变化极大, 主要

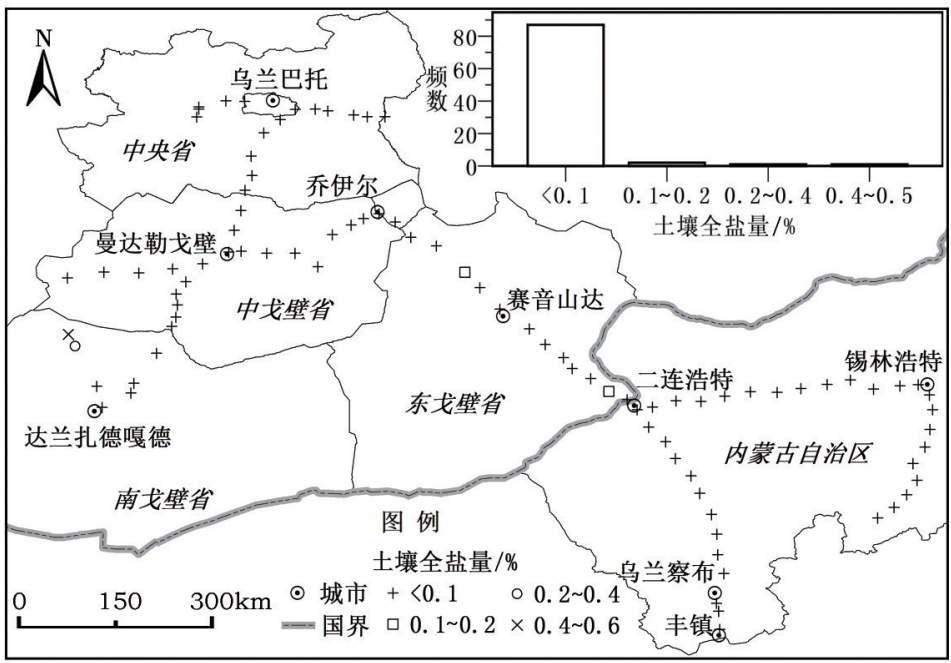

图 7 土壤全盐量的空间分布

Figure 7 The spatial distribution of soil salt content

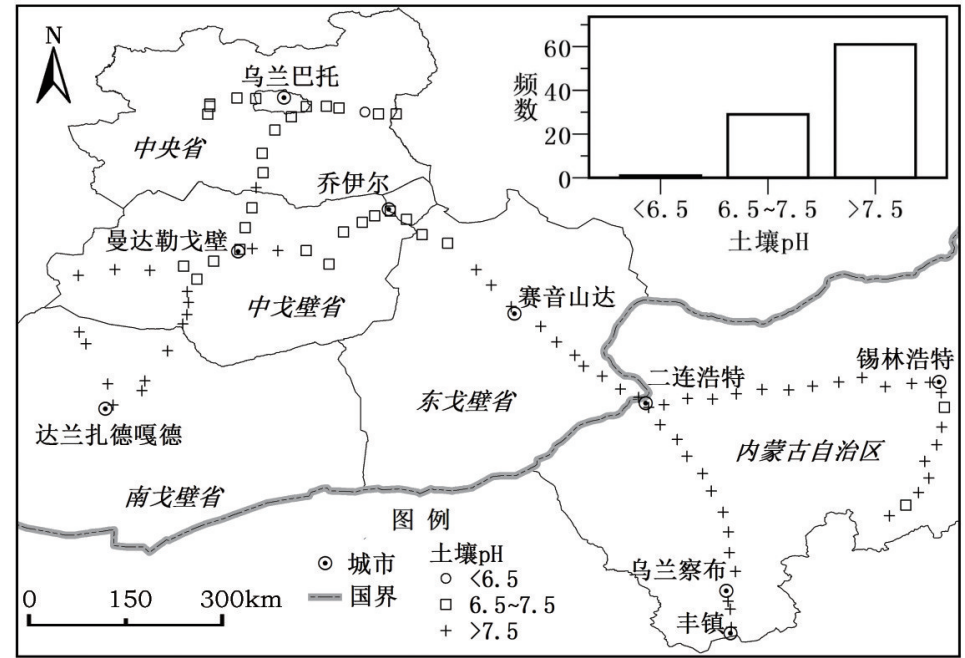

图 8 土壤 $\mathrm{pH}$ 的空间分布

Figure 8 The spatial distribution of soil $\mathrm{pH}$ 
取决于成土母质类型、有机质含量和人为因素的影 响。土壤全氮、速效磷和速效钾是表征土壤肥力的 重要因子。土壤有机质作为土壤的重要组成成分, 是表征土壤质量的重要因子。土壤有机质的变化 在土地荒漠化和草场退化中起着关键的作用,其空 间分布模式与该地区生态系统发育和演化特征密 切关联 ${ }^{[20]}$ 。土壤有机质、全氮、速效磷和速效钾参照 全国第二次土壤普查土壤养分分级标准来划分 (表 $1)^{[21]}$ 。

从土壤有机质的空间分布看, 呈现出南北高、 中间低的特点, 与植被覆盖度、植物种类数量的空 间分布规律相似(图9)。乌兰巴托、锡林浩特、乌兰 察布附近土壤有机质含量丰富, 蒙古国中戈壁省、 东戈壁省赛音山达附近和中国内蒙古二连浩特附 近土壤有机质含量极贫乏。从具体的统计指标来 看, 土壤有机质最小值仅为 $0.1 \%$,最大值为 $5.1 \%$, 平均值为 $1.1 \%$,标准差为 $0.9 \%$, 变异系数为 $81.8 \%$, 空间变异强。
从土壤全氮的空间分布看, 呈现南部高, 北部 和中间低的特点。蒙古国境内土壤全氮极贫乏、中 国内蒙古境内土壤全氮相对丰富(图 10), 从一个侧 面反映了内蒙古境内相对发达的农业开发和人类 活动影响。

从土壤速效磷的空间分布看, 呈现出与土壤全 氮相反的态势, 即北部和中部土壤速效磷含量高, 南部低(图 11)。蒙古国境内土壤速效磷含量丰富、 内蒙古境内土壤速效磷相对贫乏。

从土壤速效钾的空间分布看, 呈现出与土壤有 机质、植被覆盖度、植物种类数量相似的空间分布 规律, 即南北土壤速效钾含量高, 中间低 (图 12)。 从具体统计指标看, 土壤速效钾含量的最小值为 $54.2 \mathrm{mg} / \mathrm{kg}$, 最大值为 $586.9 \mathrm{mg} / \mathrm{kg}$, 平均值为 $159.2 \mathrm{mg} / \mathrm{kg}$, 标准差为 $72.1 \mathrm{mg} / \mathrm{kg}$, 变异系数为 $45.0 \%$, 空间变异 中等。

4.2.4 土壤颗粒组成的空间分布特征

土壤的颗粒组成也称为土壤的机械组成或土

表 1 全国第二次土壤普查土壤养分分级标准

Table 1 The grading standard of soil nutrient for the second soil general investigation of China

\begin{tabular}{lrrrrrr}
\hline \multirow{2}{*}{ 养分指标 } & \multicolumn{7}{c}{ 养分等级 } \\
\cline { 2 - 7 } & 极贫乏 & \multicolumn{1}{c}{ 贫乏 } & \multicolumn{1}{c}{ 适量 } & 较丰富 & \multicolumn{1}{c}{ 丰富 } & 极丰富 \\
\hline 有机质 $/ \%$ & $<0.60$ & $0.6 ~ 1.0$ & $1.00 ~ 2.00$ & $2.00 ~ 3.00$ & $3.00 \sim 4.00$ & $>4.00$ \\
全氮 $/ \%$ & $<0.05$ & $0.05 \sim 0.075$ & $0.075 \sim 0.10$ & $0.10 \sim 0.15$ & $0.15 \sim 0.20$ & $>0.20$ \\
速效磷 $/(\mathrm{mg} / \mathrm{kg})$ & $<3$ & $3 \sim 5$ & $5 \sim 10$ & $10-20$ & $20 \sim 40$ & $>40$ \\
速效钾 $/(\mathrm{mg} / \mathrm{kg})$ & $<30$ & $30 \sim 50$ & $50 \sim 100$ & $100-150$ & $150-200$ & $>200$ \\
\hline
\end{tabular}

注:土壤养分分级标准引自文献[21]。

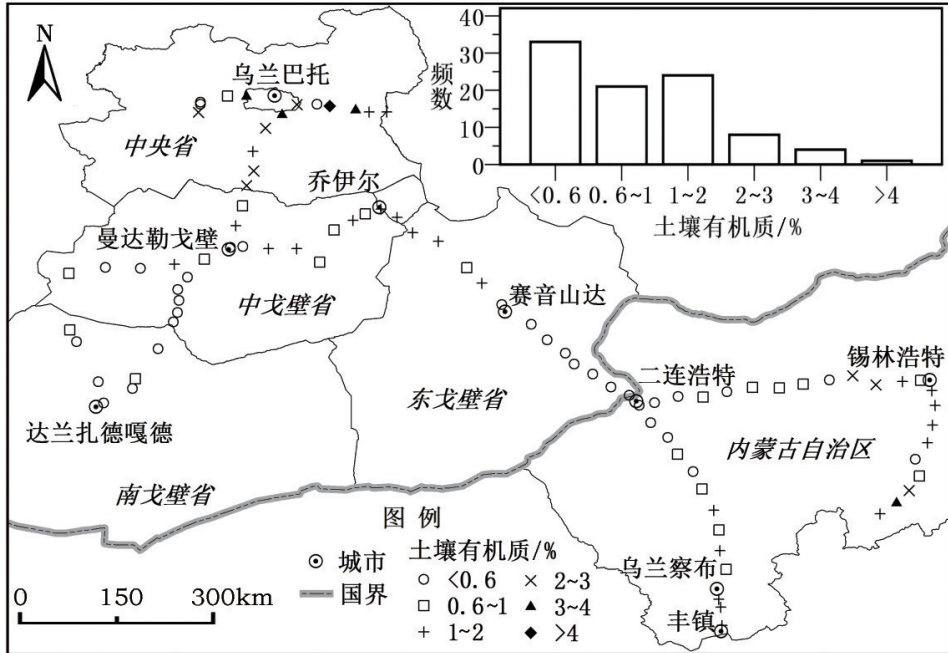

图9 土壤有机质的空间分布

Figure 9 The spatial distribution of soil organic matter 


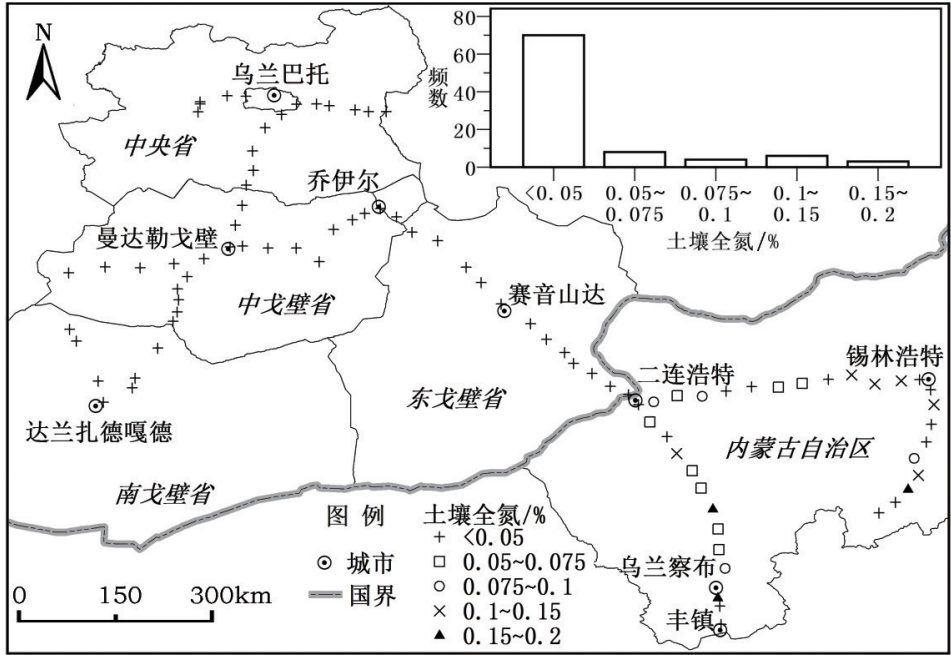

图 10 土壤全氮的空间分布

Figure 10 The spatial distribution of total soil Nitrogen

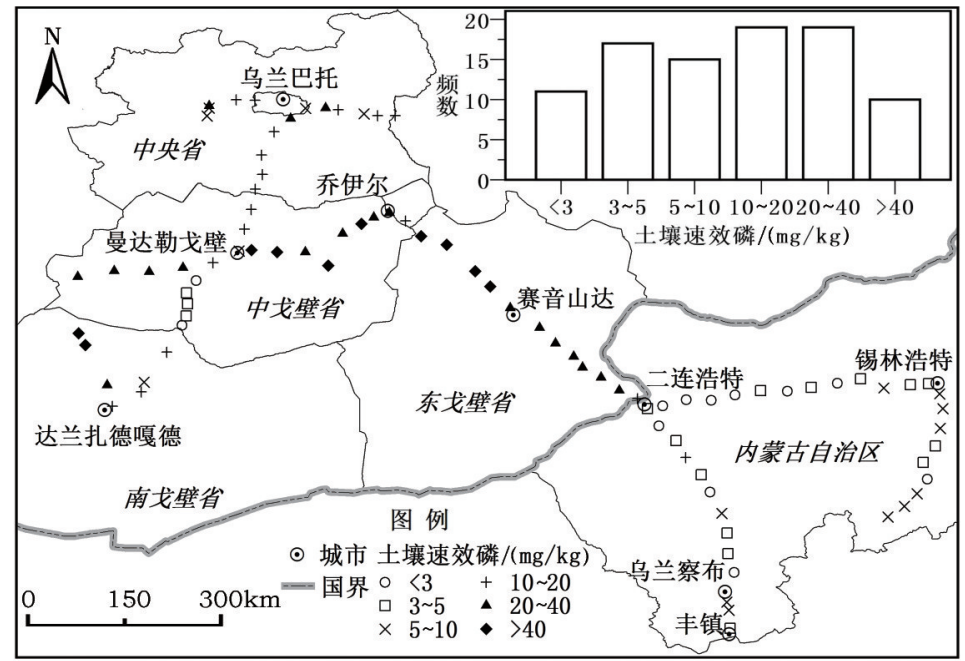

图 11 土壤速效磷的空间分布

Figure 11 The spatial distribution of soil available phosphorus

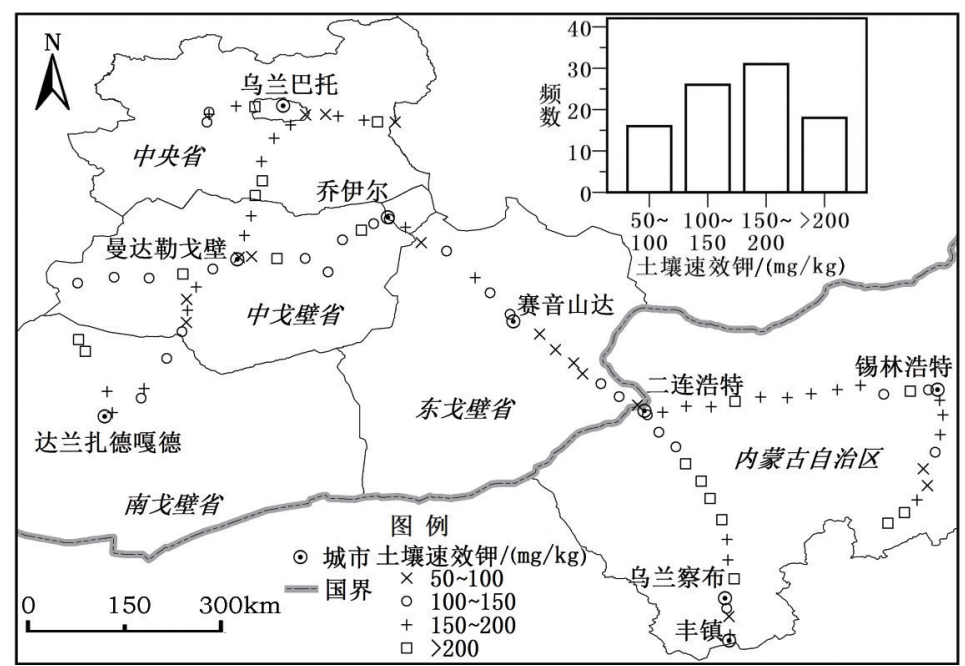

图 12 土壤速效钾的空间分布

Figure 12 The spatial distribution of soil available potassium 
壤质地,土壤颗粒根据粒径大小分为砂粒、粉粒和 黏粒三级, 根据各级的含量比例进行土壤质地划 分。土壤质地影响到土壤的通透性、持水性、保肥、 紧实度和粘结性等诸多特性, 与荒漠化的发展及植 被恢复有着密切的联系 ${ }^{[5]}$ 。

蒙古高原乌兰巴托-丰镇草地样带土壤砂粒百 分比普遍较高, $64.8 \%$ 的土壤样品中砂粒百分比大 于 $50.0 \%, 34.1 \%$ 的土壤样品中砂粒百分比大于 $65.0 \%, 80.2 \%$ 的土壤样品中黏粒百分比小于 $18.0 \%$,以砂壤土、粉砂壤土居多。

从土壤砂粒百分比的空间分布看,呈现出与土 壤有机质、土壤速效钾、植被覆盖度、植物种类数量
相似的空间分布规律, 即南北土壤砂粒百分比高, 中间低(图 13)。土壤砂粒百分比低值区对应于赛 音山达-二连浩特一线荒漠化严重的区域。土壤砂 粒百分比最小值为 $20.7 \%$ 、最大值为 $95.0 \%$ 、平均值 为 $58.7 \%$,标准差 $18.0 \%$, 变异系数 $30.7 \%$ 。

从土壤粉粒百分比的空间分布看,呈现出与土 壤砂粒百分比相反的规律, 即中间高、南北低。土 壤粉粒百分比高的区域正好是赛音山达-二连浩特 一线荒漠化严重的区域。土壤粉粒百分比的最小 值为 $4.9 \%$ 、最大值为 $56.8 \%$ 、平均值为 $31.5 \%$, 标准 差 $11.8 \%$,变异系数 $37.5 \%$ 。

从土壤黏粒百分比的空间分布看(图 14),乌兰

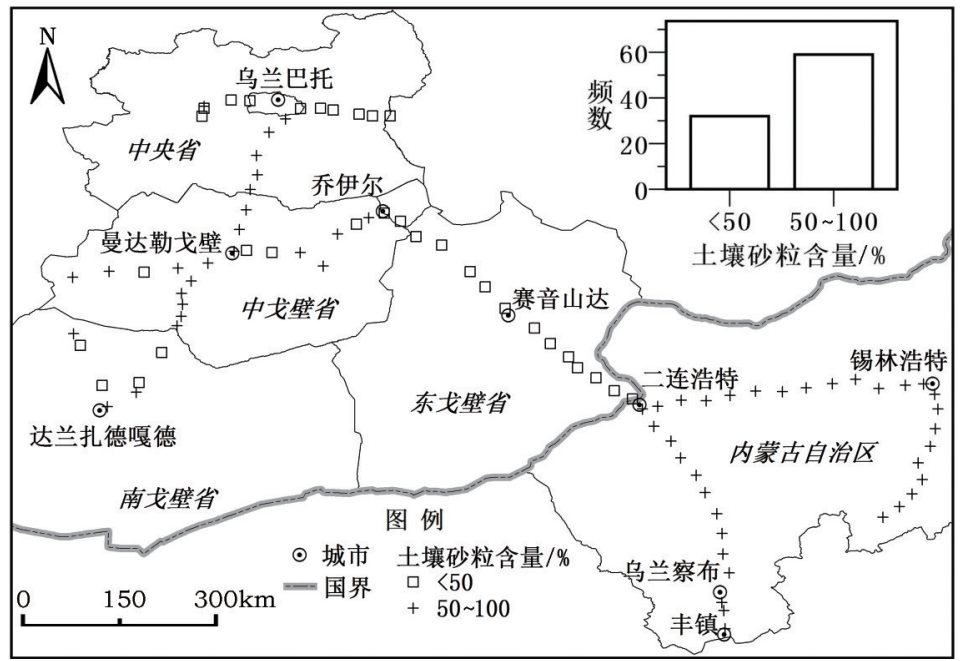

图 13 土壤砂粒百分含量的空间分布

Figure 13 The spatial distribution of soil sand particle fraction

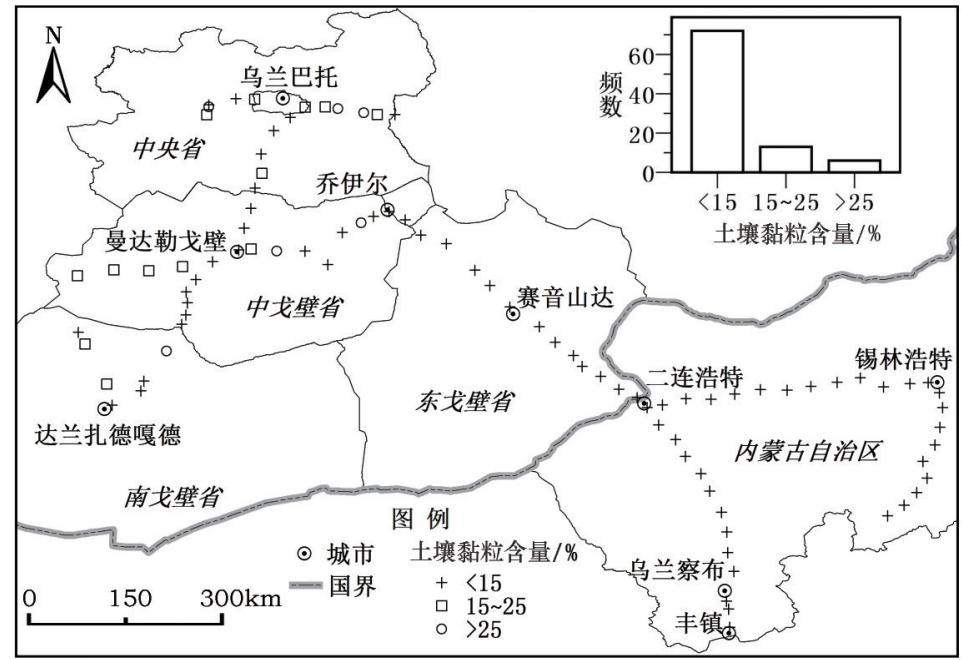

图 14 土壤稳粒百分含量的空间分布

Figure 14 The spatial distribution of soil clay particle fraction 
巴托附近土壤黏粒百分比相对较高, 其它地区土壤 黏粒百分比相对较低。土壤黏粒百分比的最小值 为 0.0 、最大值为 $38.2 \%$ 、平均值为 $9.8 \%$, 标准差 9.2 , 变异系数 $93.9 \%$ 。

\section{5 结论}

本文基于 2013 年 8 月蒙古高原乌兰巴托-丰镇 草地样带植被与土壤调查数据, 对其空间分布特征 进行了分析, 获得了如下主要结论:

(1)蒙古高原乌兰巴托-丰镇草地样带上, 植被 覆盖度、植物种类数量、土壤有机质、土壤速效钾、 土壤砂粒百分比具有相似的空间分布规律, 呈现南 北高,中间低的空间分布形态。

(2)蒙古国境内的草地样方出现灌丛的现象比 中国内蒙古境内多,从一个侧面反映了蒙古国草地 退化相对更严重。

(3) 蒙古高原乌兰巴托-丰镇草地样带上, 土壤 相对干旱、土壤盐渍化程度轻。蒙古国境内土壤以 中性为主, 中国内蒙古境内土壤以碱性为主。

(4) 乌兰巴托、锡林浩特、乌兰察布附近土壤有 机质含量丰富,蒙古国中戈壁省、东戈壁省赛音山 达附近和中国内蒙古二连浩特附近土壤有机质含 量极贫乏。蒙古国境内土壤全氮极贫乏、中国内蒙 古境内土壤全氮相对丰富,从一个侧面反映了中国 内蒙古境内相对发达的农业开发和人类活动影响。

(5)蒙古高原土壤速效钾相对丰富。蒙古国境 内土壤速效磷含量丰富、中国内蒙古境内土壤速效 磷相对贫乏。

由于本文的研究是基于一次科学考察的成果, 考察目标有限, 因此分析结果难免有所偏颇, 但植 物种类数量等指标研究结果与前人所得结论一致, 说明本研究成果在某种程度上是可以信赖的,可为 区域植被恢复和荒漠化防治提供资料支撑。当然， 文中土壤温湿度为瞬时实测值, 其受所测时间影响 很大, 研究结论仅供参考。总之, 蒙古高原地域广、 环境艰苦, 对其研究尚不深人,尤其缺乏植被、土壤 的系统调查分析,挖掘植被、土壤等方面反映荒漠 化的表征指标仍需将来不断深人地研究。

致谢: 蒙古高原乌兰巴托-丰镇草地样带植被 与土壤调查野外工作得到了中国科学院地理科学
与资源研究所王荵、刘兆飞、余国安、刘通、白雪红 博士、桂朝、荆金和姜亚东女士的大力协助, 得到了 蒙古地理所 Batbuyan Batjav 博士等的大力支持, 在 此表示感谢。

\section{参考文献(References) :}

[1] 国家林业局.第四次中国荒漠化和沙化状况公报 $[\mathrm{EB} / \mathrm{OL}]$. (2011- 01) [2016- 04]. http://www.china.com.cn/zhibo/zhuanti/ ch-xinwen/2010-08/31/content_21669628.htm. [State Forestry Administration of the People's Republic of China. The Fourth Bulletin on Status of Desertification and Sandification in China [EB/OL]. (2011- 01) [2016- 04]. http ://www.china.com.cn/zhibo/ zhuanti/ch-xinwen/2010-08/31/content_21669628.htm.]

[2] 王涛. 干旱区绿洲化、荒漠化研究的进展与趋势[J]. 中国沙漠, 2009, 29 (1) : 1-9. [Wang T. Review and prospect of research on oasification and desertification in arid regions[J]. Journal of Desert Research,2009,29(1):1-9.]

[3] 李新荣. 干旱沙区土壤空间异质性变化对植被恢复的影响[J]. 中国科学 D 辑: 地球科学, 2005, 35(4) : 361-370. [Li X R. Effect of soil spatial heterogeneity variation on vegetation restoration in arid sandy regions[J]. Science in China (Ser. D: Earth Sciences ) ,2005,35(4):361-370.]

[4] 刘树林, 王涛. 浑善达克沙地的土地沙漠化过程研究[J]. 中国 沙漠, 2007, 27 (5) : 719-724. [Liu S L, Wang T. Study on land desertification process in Hunshandake Sandy land[J]. Journal of Desert Research, 2007,27(5):719-724.]

[5] 张继义, 王娟, 赵哈林. 沙地植被恢复过程土壤颗粒组成变化 及其空间变异特征[J]. 水土保持学报,2009,23(3)：153-157.

[Zhang J Y, Wang J, Zhao H L. Changes in soil particles fraction and its spatial variation characteristics in restoration processes of sandy desertification land[J]. Journal of Soil and Water Conservation, 2009,23(3): 153-157.]

［6]殷贺,李正国,王仰麟, 等. 基于时间序列植被特征的内蒙古荒 漠化评价[J]. 地理学报,2011,66(5):653-661. [Yin H,Li Z G, Wang Y L, et al. Assessment of desertification using time series analysis of hyper-temporal vegetation indicator in Inner Mongolia [J]. Acta Geographica Sinica, 2011,66(5) :653-661.]

[7] 陈鹏, 初雨, 顾峰雪, 等. 绿洲-荒漠过渡带景观的植被与土壤 特征要素的空间异质性分析[J]. 应用生态学报, 2003,14(6): 904-908. [Chen P, Chu Y, Gu F X, et al. Spatial heterogeneity of vegetation and soil characteristics in oasis- desert ecotone[J]. Chinese Journal of Applied Ecology, 2003, 14(6):904-908.]

[8] 李从娟, 雷加强, 徐新文, 等. 古尔班通古特沙漠土壤水分与化 学性质的空间分布 [J]. 生态学报, 2014,34(15):4380-4389. 
[Li C J, Lei J Q, Xu X W, et al. Spatial pattern for soil water and chemical properties in Gurbantunggut Desert[J]. Acta Ecologica Sinica , 2014,34(15) :4380-4389.]

[9] 杨梅焕,朱志梅,曹明明,等. 毛乌素沙地东南缘不同沙漠化阶 段土壤-植被关系研究[J]. 西北农林科技大学学报 (自然科学 版), 2010,38(5): 181-187. [Yang M H, Zhu Z M, Cao M M, et al. Study on the correlation of soil-vegetation in different desertification stages on the southeastern edge of $\mathrm{Mu}$ Us sandy land[J]. Journal of Northwest A \& F University (Nat. Sci. Ed.) ,2010, 38 (5) : 181-187.]

[10] 巴图娜存, 胡云锋, 毕力格吉夫, 等. 蒙古高原乌兰巴托-锡林 浩特草地样带植物物种的空间分布[J]. 自然资源学报, 2015, 30 (1) : 24-36. [Batunacun, Hu Y F, Biligejifu, et al. Spatial distribution and variety of grass species on the Ulan BatorXilinhot transect of Mongolian Plateau[J]. Journal of Natural Resources, 2015,30(1):24-36.]

[11] 周锡钦,师华定, 王秀茹. 气候变化和人类活动对蒙古高原植 被覆盖变化的影响[J]. 干旱区研究, 2014,31 (4) : 604-610. [Zhou X Y, Shi H D, Wang X R. Impact of climate change and human activities on vegetation coverage in the Mongolian Plateau [J]. Arid Zone Research ,2014,31(4) : 604-610.]

[12] 王芯,李虎. 2001-2010年蒙古国 MODIS_NDVI 时空变化监测 分析[J]. 地球信息科学学报,2011,13(5):665-671. [Wang R, Li H. Spatio-temporal changes of vegetation in Mongolia based on MODIS-NDVI during 2001-2010[J]. Journal of Geo-Information Science, $2011,13(5): 665-671$.]

[13] Eckert S, Husler F, Liniger H, et al. Trend analysis of MODIS NDVI time series for detecting land degradation and regeneration in Mongolia[J]. Journal of Arid Environments, 2015,113(2) : 1628.

[14] 周锡钦,师华定, 王秀茹, 等. 蒙古高原近 30 年土地利用变化时 空特征与动因分析[J]. 浙江农业学报,2012,24(6)：11021110. [Zhou X Y, Shi H D, Wang X R, et al. Study on the temporal and spatial dynamic changes of land use and driving forces analysis of Mongolia Plateau in recent 30 years[J]. Acta
Agriculture Zhejiangensis, 2012,24(6) : 1102-1110.]

[15] 魏云洁,甄霖,刘雪林,等. 1992-2005 年蒙古国土地利用变化 及其驱动因素 [J]. 应用生态学报, 2008, 19 (9) : 1995-2002.

[Wei Y J,Zhen L, Liu X L, et al. Land use change and its driving factors in Mongolia from 1992 to 2005[J]. Chinese Journal of Applied Ecology, 2008, 19(9): 1995-2002.]

[16] 师华定,周锡钦,孟凡浩, 等. 30 年来蒙古国和内蒙古的 LUCC 区域分异[J]. 地球信息科学学报, 2013,15(5):719-725. [Shi H D, Zhou X Q, Meng F H, et al. Mongolia and Inner Mongolia LUCC regional differentiation over the past 30 years[J]. Journal of Geo-Information Science, 2013,15(5):719-725.]

[17] 刘纪远,齐永清,师华定, 等.蒙古高原塔里亚特-锡林郭勒样带 土壤风蚀速率的 $137 \mathrm{Cs}$ 示踪分析[J]. 科学通报, 2007,52(23): 2785-2791. [Liu J Y, Qi Y Q, Shi H D, et al. 137Cs tracer analysis to estimate rates of soil windy erosion on the TaliaXinlingol transect of Mongolia Plateau[J]. Chinese Science Bulletin,2007,52(23):2785-2791.]

[18] 庆沙那. 蒙古高原放牧制度研究[D]. 呼和浩特: 内蒙古大学, 2014. [Qing S N. Grazing System in Mongolia Plateau[D]. Hohhot: Inner Mongolia University, 2014.]

[19] 李西开,蒋柏潘,袁可能. 土壤农业化学常规分析方法 $[\mathrm{M}]$. 北 京: 科学出版社, 1983. [Li Y K, Jiang B P, Yuan K N. Conventional Analytical Method of Soil Agricultural Chemistry [M]. Beijing: Science Press, 1983 .]

[20] 王合玲,张辉国,秦璐,等. 新疆艾比湖流域土壤有机质的空间 分布特征及其影响因素[J]. 生态学报, 2012,32(16) : 49694980. [Wang H L, Zhang H G, Qin L, et al. The characteristics of the spatial distribution of soil organic matter and factors influencing it in Ebinur Lake Basin of Xinjiang Autonomous Region, China[J]. Acta Ecologica Sinica, 2012, 32 (16) : 49694980.]

[21］全国土壤普查办公室.《全国第二次土壤普查暂行技术规程》 [M]. 北京: 农业出版社, 1979. [National Soil Survey Office Interim technical regulations for the second national general survey of soil[M]. Beijing: Agriculture Press, 1979.] 


\title{
Spatial distribution of vegetation and soil properties on the Ulan Bator-Fengzhen transect on the Mongolian Plateau
}

\author{
LIU Qingsheng ${ }^{1,2}$, LIU Gaohuan ${ }^{1}$, HUANG Chong ${ }^{1}$, YAO Zhijun ${ }^{3}$, HUANG Heqing ${ }^{3}$ \\ (1. State Key Laboratory of Resources and Environment Information System, Institute of Geographic Sciences and Natural Resources Research, \\ Chinese Academy of Sciences, Beijing 100101, China; \\ 2. Jiangsu Center for Collaborative Innovation in Geographical Information Resource Development and Application, Nanjing 210023, China; \\ 3. Institute of Geographic Sciences and Natural Resources Research, Chinese Academy of Sciences, Beijing 100101, China; )
}

\begin{abstract}
Desertification is a major global environmental problem. Vegetation and soil are the main targets of land desertification research. Comprehensive analysis of vegetation and soil properties and their spatial distribution are important for combating desertification and restoring vegetation in arid and semi arid regions. Based on vegetation and soil investigation data for the Ulan Bator- Fengzhen transect acquired in August 2013, the spatial distribution and statistical characteristics of vegetation and soil were studied. We found that vegetation coverage, number of plant species, soil organic matter, soil available potassium and soil sand percentage along the Ulan Bator- Fengzhen transect have a similar spatial distribution characteristics whereby high values exist in northern and southern parts of the transect (Ulan Bator, Dundgovi of Mongolia, and Xilinhot, Ulanqab of Inner Mongolia, China) and low values exist in the center (From Dornogovi of Mongolia to Erenhot of Inner Mongolia, China). In general, soils of the Ulan Bator-Fengzhen transect are drier, and the degree of soil salinization is minor. The majority of soils in Mongolian parts of the transect belong to neutral soils, and soils in the Inner Mongolian parts of the transect are alkaline. A brush exists in the sampling sites of Mongolia more frequently than in Inner Mongolia which indicates that grassland desertification in Mongolia is more serious. Soils in the Mongolian transect lack total nitrogen, and conversely, soils in the Inner Mongolian transect have abundant total nitrogen, reflecting the relatively developed agriculture and human activities in Inner Mongolia. The results from this paper provide a scientific basis for prevention and control of desertification on the Mongolian Plateau.
\end{abstract}

Key words : Mongolian Plateau; grassland transect; vegetation; soil properties ; spatial distribution 